\title{
The glutaraldehyde test and its use in dairy cattle
}

\section{O teste do glutaraldeído e seu uso em bovinos de leite}

\author{
Elizabeth Ertal Bernarski1 ${ }^{1}$ Kassy Gomes da Silva ${ }^{1}$; Ligia Valéria Nascimento ${ }^{1}$; \\ Saulo Henrique Weber ${ }^{2}$; Cristina Santos Sotomaior ${ }^{3}$; Ivan Roque de Barros Filho; \\ Alexander Starke ${ }^{5}$; Rudiger Daniel Ollhoff ${ }^{6 *}$
}

\begin{abstract}
During a physical examination of cattle, it is often difficult to evaluate inflammatory processes, particularly in cases where the inflammation occurs in deeper regions. The glutaraldehyde test (GT), carried out using a sample of whole blood, allows the visual and semiquantitative identification of an inflammatory process in cattle. Considering that there are few biochemical tests that can be used in the field, the objective of this study was to verify the efficacy of the GT in detecting and predicting mild and severe inflammatory processes in bovine species, classified according to a physical examination, and in the presence of different diseases or lesions. The GT was used in conjunction with a physical examination in 176 cows over 12 months of age, with additional laboratory evaluations of packed cell volume, total protein, albumin, globulin, and fibrinogen. Using a cutoff point at 3 minutes of coagulation, the GT showed a sensitivity of $35.1 \%$, specificity of $94.1 \%$, positive predictive value of $74.1 \%$, and negative predictive value of $75.2 \%$. The GT correctly detected the most severe inflammatory processes under the field conditions of this study. The GT is a diagnostic aid that can be used as a fast and simple screening test during the physical examination of cattle.
\end{abstract}

Key words: Cow. Diagnosis. Glutaraldehyde Test. Inflammatory process.

\section{Resumo}

Processos inflamatórios em bovinos, principalmente quando ocorrem em regiões mais profundas, são difíceis de avaliar no exame físico. O teste de glutaraldeído (TG), realizado com uma amostra de sangue total, possibilita a identificação visual e semiquantitativa de um processo inflamatório no bovino. Ao considerar que existem poucos testes bioquímicos passíveis de aplicação a campo, esse estudo objetivou verificar a eficácia do TG em detectar e predizer os processos inflamatórios leve e grave classificados conforme o exame físico e na presença de diferentes doenças ou lesões na espécie bovina. O TG foi aplicado juntamente com o exame físico em 176 fêmeas bovinas acima de 12 meses, além da avaliação laboratorial do volume globular, proteína total, albumina, globulina e fibrinogênio. O TG obteve

1 Discentes, Programa de Pós-Graduação em Ciência Animal, Pontifícia Universidade Católica do Paraná, PPGCA/PUCPR, Curitiba, PR, Brasil. E-mail: elizabethertall@gmail.com; kgomes13@hotmail.com; ligiavaleria.nascimento@gmail.com

2 Prof., Programa de Pós-Graduação em Ciência Animal da Pontifícia PPGC/PUCPR, Curitiba, PR, Brasil. E-mail: saulo.weber@, pucpr.br

3 Prof ${ }^{a}$, Programa de Pós-Graduação em Ciência Animal, PPGCA/PUCPR, Curitiba, PR, Brasil. E-mail: cristina.sotomaior@ pucpr.br

4 Prof., Programa de Pós-Graduação em Ciência Veterinárias, Universidade Federal do Paraná, UFPR, Curitiba, PR, Brasil. E-mail: ivanbarf@ufpr.br

5 Prof., Faculdade de Medicina Veterinária da Universidade de Leipzig, Leipzig, Alemanha. E-mail: alexander.starke@vetmed. uni-leipzig.de

6 Prof., Programa de Pós-Graduação em Ciência Animal, PPGCA/PUCPR, Curitiba, PR, Brasil. E-mail: ollhoff@gmail.com

* Author for correspondence 
sensibilidade de $35,1 \%$, especificidade de $94,1 \%$, valor preditivo positivo de $74,1 \%$ e valor preditivo negativo de 74,2 \% com o ponto de corte em 3 minutos de tempo de coagulação. O TG foi capaz de detectar corretamente os processos inflamatórios mais graves nas condições de campo deste estudo. $\mathrm{O}$ teste constitui um recurso de auxílio diagnóstico, podendo servir como triagem pela sua rapidez e facilidade de aplicação durante o exame em bovinos.

Palavras-chave: Vaca. Diagnóstico. Teste de Glutaraldeído. Processos inflamatórios.

\section{Introduction}

Both infectious and traumatic diseases trigger inflammatory processes (IP) in animals (MEDZHITOV, 2008). However, recognizing the presence of inflammation and determining the prognosis may be difficult for clinical veterinarians, particularly if the process is chronic and implies a decision regarding the possibility of euthanasia (DOLL et al., 1985).

Complementary tests are necessary to fully interpret the findings obtained through physical examination and confirm a case of IP, because such tests result in a more reliable diagnosis (DOLL et al., 1985). Laboratory tests are important complements to physical examination, as they yield information regarding an animal's clinical condition and aid in making a diagnosis and prognosis (DIRKSEN et al., 1993). However, such examinations often require expensive equipment and laboratory facilities, and therefore field veterinarians cannot use them for cattle on a routine basis. Thus, a rapid diagnostic test, such as the glutaraldehyde test (GT), is useful during the clinical examination of cattle. The GT can provide rapid confirmation of a suspected IP (DOLL et al., 1985; KOVÁČ et al., 1987; BRINK et al., 2005; METZNER et al., 2007). The advantages of not having to send tissue samples to a laboratory for analysis are evident in terms of both logistics and economy (LIBERG, 1978; BRINK et al., 2005).

The GT is based on the capacity of glutaraldehyde to bind to proteins in dilute solutions, depending on the amount and structural arrangement of free amino groups, forming a macroscopic intermolecular gel network (SANDHOLM, 1974). The time taken for this chemical reaction to occur is inversely proportional to the concentration of fibrinogen and immunoglobulins (BRINK et al., 2005).
The diagnosis improves the prognosis, which in turn determines the possibilities of therapeutic intervention, cost, and treatment effectiveness, thereby emphasizing the importance of GT in food animal (DOLL et al., 1985; BRINK et al., 2005). Insignificant inflammatory responses and earlystage diseases can, however, result in a negative GT (DOLL et al., 1985). According to Metzner et al. (2007), an adult cow becomes GT positive after at least 7 days, and negative again after at least 21 days.

In Brazil, the GT has been used only in calves because of its capacity to react to immunoglobulins, with the aim of evaluating the degree of immunoglobulin transfer via colostrum (CHARLES et al., 1994). Tyler et al. (1996) considered that the sensitivity and specificity of the test in calves are inadequate to justify the use of the GT in monitoring the passive transfer of immunoglobulins. Although the use of the GT to detect IP in cattle has not been reported in the reviewed Brazilian literature, it has been used in European countries for this purpose (LIBERG, 1978; DOLL et al., 1985; KOVÁČ et al., 1987; BRINK et al., 2005; METZNER et al., 2007).

The objective of this study was to evaluate the use for the GT as an auxiliary method of clinical examination in yearling and adult cattle under subtropical Brazilian conditions, to assess its efficacy in detecting IP (mild and severe), and distinguishing between diseased and healthy cows.

\section{Material and Methods}

The study was carried out using lactating and non-lactating Holstein, Jersey, and Holstein-Jersey crossbred cows, aged between 12 months and 13 years old, and maintained in intensive and semi- 
intensive management systems on two dairy farms located in the municipalities of Lapa and Fazenda Rio Grande, Paraná. This study was approved by the Animal Ethics Committee (AEC) of Pontifícia Universidade Católica do Paraná (PUCPR) under the number $984 \mathrm{~A} / 2015$.

The evaluations performed included a physical examination, laboratory tests, and the GT. The physical examination (DIRKSEN et al., 1993) included the measurement of respiratory rate (RR), heart rate (HR), frequency of ruminal movements (RM), rectal body temperature (RT), skin inspection to check for the presence of lesions and ectoparasites, and body condition score (BCS). As recommended by Sprecher et al. (1997), the locomotion score (LS) was also evaluated, with results varying from 1 to 5 , with grade 1 representing non-claudication and grade 5 severe claudication and reluctance to bear weight on the affected limb. During the physical examination, the cows were classified as cases with symptoms consistent with a severe inflammatory process (SIP) (e.g., mastitis, pneumonia, and deep wounds) or mild inflammatory process/healthy (MIP) (low evidence of inflammation; e.g., presence of a few localized botfly larvae and superficial skin injury). The term MIP was used instead of healthy because as the physical examinations were very meticulous, we invariably detected some type of skin wound in the animals.
For laboratory tests and the GT, three blood samples were collected from tail vessels (coccygeal), one collected into an EDTA K2 tube used immediately for the GT, whereas the other two were stored, one in an tube without anticoagulant for the measurement of albumin (ALB), and other with EDTA for packed cell volume (PCV), total proteins (TP), and fibrinogen (FIB). Globulins (GLOs) were measured by subtracting the ALB value from that of the total plasma proteins (TPP). The ALB/GLO ratio was also calculated. ALB was measured using the bromocresol green method using an Albumin PP commercial kit (Gold Analisa Diagnóstico ${ }^{\circledR}$, Belo Horizonte, Brazil) and spectrophotometric readings (Bioplus Bio-2000®, Barueri, Brazil). The PCV, TPP (through refractometry), and FIB (Thrall, et al. 2012) were measured in plasma.

A solution prepared from $50 \mathrm{~mL}$ of $25 \%$ glutaraldehyde, $1 \mathrm{~g}$ of $\mathrm{Na}_{2}$-EDTA, and 1 liter of $0.9 \% \mathrm{NaCl}$ solution (saline) was used for the GT. The components were mixed homogeneously and maintained in dark glass receptacles for optimal storage. For the test, $2 \mathrm{~mL}$ of blood was collected and mixed with $2 \mathrm{~mL}$ of the aforementioned glutaraldehyde solution in an anticoagulant collection tube ( $\mathrm{K}_{2}$-EDTA) (DOLL et al., 1985). The GT was measured for up to 15 minutes or until coagulation (DOLL et al., 1985). A digital chronometer was used to keep time, and the results were classified from 1 to 4 according to the criteria presented in Table 1.

Table 1. Criteria of interpretation of the glutaraldehyde coagulation test (GT) and classification of the time to coagulate as well as classification of the inflammatory process, adapted from DOLL et al. (1985).

\begin{tabular}{cccc}
\hline GT Category & Coagulation time TG & Interpretation & Inflammatory process \\
\hline 1 & $0-\leq 3$ minutes & $\begin{array}{c}\text { High increase in concentration of fibrinogen } \\
\text { and / or immunoglobulin }\end{array}$ & Severe \\
\hline 2 & $>3-\leq 6$ minutes & $\begin{array}{c}\text { Moderate increase in concentration of fibrino- } \\
\text { gen and/or immunoglobulin }\end{array}$ & Moderate \\
\hline 3 & $>6-\leq 15$ minutes & $\begin{array}{c}\text { Low increase in concentration of fibrinogen } \\
\text { and/or immunoglobulin }\end{array}$ & Mild \\
\hline 4 & $>15$ minutes & $\begin{array}{c}\text { No increase in concentration of fibrinogen } \\
\text { and/or immunoglobulin }\end{array}$ & Not detectable \\
\hline
\end{tabular}


The physical examination data (RR, HR, RM, RT, skin or subcutaneous inspection, and the presence of ectoparasites) (DIRKSEN et al., 1993) and the laboratory tests (ALB, TPP, GLO, FIB, and PCV) were used to provide information on the animals' health status. Biochemical and physiological values were described according to Kaneko et al. (2008).

Sensitivity (SE), specificity (SP), positive predictive value (PPV), and negative predictive value (NPV) were calculated according to Kawamura (2002), based on the following criteria. If the physical examination and/or laboratory tests suggested IP, with presence of fever and increased FIB, it was considered that the animal should react to the GT. For the calculation of SE and SP, the cutoff point was 3 minutes (category 1 in the GT). Discrepancies were considered as false negative (GT category 2, 3, or 4, with symptomatology consistent with SIP) or false positives (GT category 1, but without symptoms consistent with SIP). PPV was calculated dividing the true positives (animals with clinical symptoms and GT1) with the sum of the true positives with the false positives (animals without symptoms other than GT1). NPV was calculated dividing the true negatives (GT test category $>1$ without symptoms) with the sum of the true negatives and the false negatives (animals with GT $>1$ but with symptoms).

The software Statgraphics ${ }^{\circledR}$ Centurion XVI version 16.1.11 was used for statistical analysis at a confidence level of $95 \%$. Pearson correlations were used for quantitative variables, and Spearman correlations for qualitative variables. In addition, the statistical analysis software GraphPad Prism ${ }^{\circledR}$ version 5.00 (San Diego, California, USA) was also used. The ANOVA test was used for the GT groups, and the Kruskal-Wallis test was used for the nonparametric data, followed by Dunn's post hoc test or the Tukey test (parametric data). Student's t-test was used for the MIP and SIP groups, and the MannWhitney test was used for the non-parametric data.

\section{Results}

Of the 176 animals examined, 119 were classified as MIP in the physical examination and the average GT time for these animals was 9 minutes and 42 seconds. The remaining 57 animals were classified as SIP, with an average GT time of 6 minutes and 20 seconds. Independent of classification into SIP or MIP, the physical examination revealed 74 cows with skin integrity lesions, most commonly skin wounds caused by Dermatobia hominis larvae (botfly larvae) and also including other kind of myiasis, traumatic hock injury, abscesses, suspected stephanofilariasis, udder wounds and infected surgical wounds. Twenty animals with fetid vaginal discharge or retained placenta; five cows with acute catarrhal mastitis; and other problems, including displaced abomasum, rib fracture and purulent nasal discharge. Nine animals showed more than one type of lesion. The classification of the animals according to their GT results and physical examination is shown in Table 2.

The mean age of the cows was of approximately 4 years (3.93), with a maximum of 13 years. The classifications according to physical examination, age, and GT categories are shown in Table 3.

The $r=-0.5185(p<0.0001)$ obtained for RR and the $r=-0.3377,(p<0.0001)$ obtained for LS indicated a correlation with GT categories. RM averaged $2.93 \pm 0.90$ for 2 minutes and HR was 81.57 \pm 13.79 beats/minute. These values are not listed in Table 3 because they did not show significant differences between categories and groups. 
Table 2. Cattle classification (number and percentage) considering physical examination in mild inflammatory process /healthy animals (MIP) and severe inflammatory process (SIP) by the glutaraldehyde test (GT) in the categories 1 to 4 .

\begin{tabular}{|c|c|c|c|c|c|c|c|}
\hline \multirow{2}{*}{ Groups } & \multicolumn{4}{|c|}{ GT Category } & \multirow{2}{*}{ Total } & \multirow{2}{*}{$\begin{array}{l}\text { Mean and standard devia- } \\
\text { tion of GT (min)* }\end{array}$} & \multirow[t]{2}{*}{ Median of GT categories } \\
\hline & 1 & 2 & 3 & 4 & & & \\
\hline MIP (n) & 7 & 23 & 69 & 20 & 119 & $9.42 \pm 4.25$ & $3^{\mathrm{a}}$ \\
\hline$(\%)$ & 5.88 & 19.33 & 57.98 & 16.81 & 67.61 & & \\
\hline $\operatorname{SIP}(n)$ & 20 & 18 & 14 & 5 & 57 & $6.20 \pm 4.19$ & $2^{\mathrm{b}}$ \\
\hline$(\%)$ & 35.09 & 31.58 & 24.56 & 8.77 & 32.39 & & \\
\hline
\end{tabular}

Different letters in the same column represent significant statistical difference between the categories $(\mathrm{p}<0.0001)$. ${ }^{*}$ Calculated from raw data.

Table 3. Mean and standard deviation of age (years), respiratory rate $-\mathrm{RR}$ (movements/min), rectal temperature $\mathrm{RT}\left({ }^{\circ} \mathrm{C}\right)$ and mean of the locomotion score (LS) of cattle, according to the different glutaraldehyde test (GT) categories (1-4) and inflammatory process groups (Mild - MIP, Severe - SIP).

\begin{tabular}{ccccc}
\hline GT Category & Age (years) & RR $(\mathrm{m} / \mathrm{min})$ & RT $\left({ }^{\circ} \mathbf{C}\right)$ & LS \\
\hline $1(\mathrm{n}=27)$ & $5.07 \pm 1.65^{\mathrm{a}}$ & $50.81 \pm 11.04^{\mathrm{a}}$ & $38.47 \pm 0.29^{\mathrm{ab}}$ & $3^{\mathrm{a}}$ \\
$2(\mathrm{n}=41)$ & $4.06 \pm 1.99^{\mathrm{ab}}$ & $47.07 \pm 13.24^{\mathrm{a}}$ & $38.65 \pm 0.49^{\mathrm{a}}$ & $2^{\mathrm{b}}$ \\
$3(\mathrm{n}=83)$ & $3.69 \pm 2.22^{\mathrm{b}}$ & $35.85 \pm 6.24^{\mathrm{b}}$ & $38.43 \pm 0.31^{\mathrm{b}}$ & $2^{\mathrm{b}}$ \\
$4(\mathrm{n}=25)$ & $3.32 \pm 1.18^{\mathrm{b}}$ & $36.48 \pm 7.86^{\mathrm{b}}$ & $38.43 \pm 0.35^{\mathrm{ab}}$ & $2^{\mathrm{b}}$ \\
\hline MIP $(\mathrm{n}=119)$ & $3.76 \pm 2.15^{\#}$ & $38.25 \pm 9.66^{\#}$ & $38.45 \pm 0.34^{\#}$ & $1^{\#}$ \\
SIP $(\mathrm{n}=57)$ & $4.29 \pm 1.70^{\# \#}$ & $46.28 \pm 12.08^{\#}$ & $38.56 \pm 0.42^{\#}$ & $2^{\# \#}$ \\
\hline Total $(\mathrm{n}=176)$ & $3.93 \pm 2.02$ & $40.85 \pm 11.13$ & $38.37 \pm 0.22$ & 2 \\
\hline
\end{tabular}

Different letters in the same column represent significant statistical difference between the categories; ${ }^{\#}$ and ${ }^{\#}$ differ in MIP and SIP scores $(\mathrm{p}<0.05)$.

Claudication was detected through GT with $\mathrm{r}=-0.3377(\mathrm{p}<0.0001)$. The mean time until coagulation for grade 1 LS $(n=67$ cows) was 9 minutes and 46 seconds in GT; grade $2(n=49$ animals) was 9 minutes and 12 seconds; grade 3 ( $n=41$ cows) was 7 minutes and 39 seconds; and grade 4 ( $n=18$ cows) was 5 minutes and 56 seconds. There was only a single cow with grade 5 LS, which had a GT of 2 minutes.

Laboratory and blood biochemical analyses showed a positive correlation between PCV and GT $(r=0.4591, p<0.0001)$. ALB, GLO, and the ALB/
GLO ratio also showed correlations with GT $[\mathrm{r}=$ $-0.4212(\mathrm{p}<0.0001), \mathrm{r}=0.2106(\mathrm{p}=0.005)$, and $r=-0.3537(p<0.0001)$, respectively]. The lower GT time for groups 1 and 2 indicates higher FIB values $(540.74 \pm 164.69$ and $436.58 \pm 154.52 \mathrm{mg} /$ $\mathrm{dL}$, respectively) (Table 4). The higher the FIB, the lower is the GT time $(\mathrm{r}=-0.3356, \mathrm{p}<0.0001)$.

On the basis of a standard physical examination and a GT cutoff point of up to 3 minutes, it was possible to calculate the sensitivity, specificity, and predictive value of the test, as shown in Table 5. 
Table 4. Table 4. Mean and standard deviation of packed cell volume - PCV (\%), total plasma proteins - TPP (g/dL), albumin - ALB $(\mathrm{g} / \mathrm{dL})$, globulin - GLO (g/dL), relation albumin to globulin (ALB/GLO) and fibrinogen - FIB (mg/ dL) of cattle, according to the different glutaraldehyde test (GT) categories (1-4) and inflammatory process groups (Mild - MIP, Severe - SIP).

\begin{tabular}{ccccccc}
\hline GT Category & PCV $(\%)$ & TPP $(\mathrm{g} / \mathrm{dL})$ & ALB $(\mathrm{g} / \mathrm{dL})$ & GLO $(\mathrm{g} / \mathrm{dL})$ & ALB/ GLO & FIB $(\mathrm{mg} / \mathrm{dL})$ \\
\hline $1(\mathrm{n}=27)$ & $26.00 \pm 2.89^{\mathrm{a}}$ & $7.78 \pm 0.46^{\mathrm{a}}$ & $3.21 \pm 0.61^{\mathrm{a}}$ & $4.22 \pm 0.93^{\mathrm{ab}}$ & $0.83 \pm 0.32^{\mathrm{ab}}$ & $540.74 \pm 164.69^{\mathrm{a}}$ \\
$2(\mathrm{n}=41)$ & $28.76 \pm 3.45^{\mathrm{b}}$ & $7.57 \pm 0.70^{\mathrm{ab}}$ & $3.43 \pm 0.74^{\mathrm{a}}$ & $3.70 \pm 1.09^{\mathrm{a}}$ & $1.03 \pm 0.41^{\mathrm{b}}$ & $436.58 \pm 154.52^{\mathrm{ab}}$ \\
$3(\mathrm{n}=83)$ & $30.10 \pm 2.90^{\mathrm{c}}$ & $7.48 \pm 0.79^{\mathrm{b}}$ & $2.67 \pm 0.60^{\mathrm{b}}$ & $4.44 \pm 0.96^{\mathrm{b}}$ & $0.65 \pm 0.28^{\mathrm{a}}$ & $375.90 \pm 146.16^{\mathrm{b}}$ \\
$4(\mathrm{n}=25)$ & $30.40 \pm 3.29^{\mathrm{bc}}$ & $7.25 \pm 0.73^{\mathrm{b}}$ & $2.75 \pm 0.67^{\mathrm{b}}$ & $4.15 \pm 0.91^{\mathrm{ab}}$ & $0.71 \pm 0.29^{\mathrm{a}}$ & $352.00 \pm 115.90^{\mathrm{b}}$ \\
\hline MIP $(\mathrm{n}=119)$ & $29.98 \pm 3.03^{\#}$ & $7.46 \pm 0.73^{\#}$ & $2.90 \pm 0.68^{\#}$ & $4.17 \pm 0.94^{\#}$ & $0.76 \pm 0.34^{\#}$ & $385.71 \pm 142.19^{\#}$ \\
SIP $(\mathrm{n}=57)$ & $27.56 \pm 3.59^{\# \#}$ & $7.72 \pm 0.75^{\# \#}$ & $3.01 \pm 0.81^{\#}$ & $4.24 \pm 1.15^{\#}$ & $0.80 \pm 0.39^{\#}$ & $466.67 \pm 177.62^{\#}$ \\
\hline Total $(\mathrm{n}=176)$ & $29.20 \pm 3.41$ & $7.54 \pm 0.74$ & $2.94 \pm 0.72$ & $4.19 \pm 1.01$ & $0.78 \pm 0.36$ & $411.93 \pm 158.65$ \\
\hline
\end{tabular}

Different letters in the same column represent significant statistical difference between the categories; ${ }^{*}$ and ${ }^{\# \#}$ differ in MIP and SIP scores $(\mathrm{p}<0.05)$.

Table 5. Sensitivity, specificity and positive (PPV) and negative (NPV) predictive values of the glutaraldehyde test for dairy cattle $(\mathrm{n}=176)$.

\begin{tabular}{cccc}
\hline Sensitivity & Specificity & PPV & NPV \\
\hline $35.1 \%$ & $94.1 \%$ & $74.1 \%$ & $75.2 \%$ \\
\hline
\end{tabular}

\section{Discussion}

By simply considering health as the absence of any disease or injury, and as health is one of the principles of bovine welfare (DE VRIES et al., 2011), we discovered that the cattle herds analyzed were not completely healthy. On the basis of a clinical examination we classified the animals into two groups according to the IP level. Most animals (67.6\%) were classified as MIP, but one-third were classified as SIP. Although these herds were selected based on convenience, they provide a representative sample in terms of management of the specialized dairy herds farmed in Paraná. This first conclusion highlights the potential for improvements in the health of our herds and for achieving higher productivity levels that are consistent with the genetic quality of herds in Paraná (PAULA et al., 2009).

We experienced no practical complications when using the GT in the field. Despite the high standard deviation, the GT correctly distinguished MIP and SIP (Table 2). According to Metzner et al. (2007), SIP should be associated with significant changes in FIB and gamma globulin values. Significant differences were found in the FIB, although not in GLO, of animals examined in this study, which had a mean value of $466 \mathrm{mg} / \mathrm{dL}$. This value is approximately $60 \%$ higher than the value of $287 \mathrm{mg} / \mathrm{dL}$ detected in German dairy cows (METZNER et al., 2007). They might have been difference of the measurement method between Metzner et al. (2007), as they used a cinetic method. Earlier results obtained in Brazil by Fagliari et al. (1998) with healthy Holstein cattle were similar to the fibrinogen values actually measured. It can be assumed that heightened interaction with a hostile immune environment in Brazil, which includes infectious diseases such as leucosis (MEIRELLES et al., 2009) and ectoparasites (ÁLVAREZ et al., 2013; ZIMMER et al., 2010), contributes to this discrepancy in results between Europe and Brazil. 
Older animals have immune systems better adapted and more responsive to different environmental challenges (CANAVESSI et al., 2000; DEVERY-POCIUS; LARSON, 1983). This observation can be corroborated by the results obtained using the GT, which under Brazilian conditions confirm the previous findings presented by Doll et al. (1985), who reported strongly positive GT reactions in cattle over 6 years of age.

In adult cows in particular, the RR, which was measured in the physical examination, was sufficiently sensitive to detect minor inflammatory problems of the lungs, which cannot be detected by inspection (DIRKSEN et al., 1993). In Brazil, an increased RR value tends to be of considerable significance, as it is related to thermal stress (PERISSINOTTO et al., 2009). However, the GT shows the great importance of IP in cattle, and may reflect the anatomical characteristics of bovine lungs and the intensive breeding of dairy cows, which contribute to the ready spread of infectious respiratory agents (VALARCHER; HÄGGLUND, 2006).

We found that body temperature was not a differential factor in terms of GT use, although it is a factor commonly assessed in practice during physical examination for the detection of infectious processes. Compared with the changes necessary for GT detection, which requires a minimum of 7 days for detection of a positive result (METZNER et al., 2007), the thermal regulation system reacts considerably more rapidly to endotoxins, which can justify the absence of correlation.

Several distal locomotor processes cause considerable local or ascending IP, including interdigital phlegmon, arthritis, and tendovaginitis (GREENOUGH, 1997). Nechanitzky et al. (2016) did not present a faster clotting time in cows with or without claudication. They observed, that if the cow has a superficial defect of the claw corium with lameness, but without severe IP, they will have clotting times longer than 5 minutes. If the clotting time is shorter, the clinician should search for another cause then claw lesions. When more superficial IPs, such as digital and interdigital dermatitis, are complicated by myiasis, which is common in Brazil, the GT will react faster accordingly. Therefore, in this cases or others with phlegmonous inflammations of the limb, the GT can also be used to identify animals with claudication.

The correlation between GT and PCV may indicate the importance of hemoparasites, including both ectoparasites and diseases such as anaplasmosis (BERNARDO et al., 2016), as more anaemic cows had also a faster reaction time with the GT.

The GT detected animals with increased FIB values, although the correlation was not strong ( $\mathrm{r}$ $=-0.3356$ ) (DOLL et al., 1985; METZNER et al., 2007), corroborating the findings of Brink et al. (2005) obtained in horses. Cows are among the domestic animals with the highest capacity to deposit fibrin around infectious-inflammatory lesions, which in chronic and severe cases can lead to the depletion of FIB reserves. In contrast, animals with serious diseases (e.g., peritonitis, pericarditis, and pneumonia) typically have FIB values greater than $800 \mathrm{mg} / \mathrm{dL}$ (MCSHERRY et al., 1970). This could be a reason why we did not detect any differences in the FIB values of MIP and SIP groups. It should be noted, however, that the mean values obtained for both groups are similar to those reported by Bagga et al. (2016) for a group of claudicating cows (average of $397 \mathrm{mg} / \mathrm{dL}$ ) and a group of healthy cattle $(140 \mathrm{mg} / \mathrm{dL})$, which corroborates the high number of claudicating animals in both herds.

That there were no significant differences between MIP and SIP groups in terms of GLO and FIB concentrations, could be explained by the not so accurate method of refractometry and calculation $(\mathrm{TTP}=\mathrm{ALB}+\mathrm{GLO})$ of the value of GLO used, although they are faster and easier to perform in simpler equipped laboratories. TPP is a more comprehensive biochemical parameter, was higher in the SIP group, which is compatible with severe inflammation (DIRKSEN et al., 1993). 
The low ALB levels in healthy animals, below the tolerance level of 3,0 g/dL (FÜRLL, 2005) in GT groups 3 and 4, was a surprising finding in the present study, as low ALB levels are assumed to be associated with the most severe inflammation processes (GT 1 or 2), or in cases of liver disease, severely reduced food intake (FÜRLL, 2005), or ALB loss caused by parasitism (GONZÁLEZ; SILVA, 2017). However, these clinical conditions would also correspond with similarly low TPP and PCV levels, which we did not observe. Peripartum cows raised under Brazilian conditions tend to have low ALB levels (ALVARENGA et al., 2017; BIRGEL JUNIOR et al., 2003) that are lower than the international reference values (FÜRLL, 2005; SMITH, 2009), which led Alvarenga et al. (2017) to advocate the use of lower national reference values, at least in this stage. It should, however, be noted that we detected no significant differences in ALB when comparing the MIP and SIP groups. Although the ALB/GLO ratio was low when compared to that reported in other national studies (FERREIRA et al., 2001), there was no relationship between this finding and the GT.

This study shows that the diagnostic sensitivity of a sign or test result in relation to a disease, in this case MIP or SIP, corresponds to the number of individuals that are positive and sick (DIRKSEN et al., 1993; KAWAMURA, 2002). In the present study, the mean sensitivity value of the GT was $35,1 \%$, whereas the test had a higher specificity of greater than 94\%. An NPV higher than 75\% can be considered a good performance for a simple and inexpensive field test. The PPV was also $74 \%$, although this value is considerably lower than the 97\% obtained by Doll et al. (1985), which can probably be explained by the fact that the cases studied by these authors were more severe than those examined in the present study.

As the specificity was greater than the sensitivity, the GT identifies individuals correctly with no IP (NPV) using a 3-minute cutoff. In this regard, Metzner et al. (2007), who used the GT, showed that cattle take about seven days to get positive in a GT and about three times longer to become negative again, with a good correlation with fibrinogen levels. The findings of the present study, in which false negatives (37 animals) were proportionally more frequent than false positives (7 animals), is consistent with this observation. False positives may also occur in healthy cows after calving (METZNER et al., 2007). Specificity and PPV contribute to the efficiency of GT as a screening test, which has been used in Germany in field examinations (STARKE, 2017).

Although the GT is a simple test, it has been referenced since the 1990s when first described by Dirksen et al. (1993). It is noteworthy, however, that only now are field tests being carried out using this test on a large scale for the detection of IP in adult cattle.

\section{Conclusions}

The GT correctly detected most SIP under the field conditions of this study, but is better used as a screening test to exclude inflammatory processes. This test should be used as a complement to physical examination. The GT is a diagnostic aid, and because of its fast and simple application during field examinations, it can be used under Brazilian field conditions. Future studies should investigate the level of interference of chronic and latent infections in GT results.

\section{References}

ALVARENGA, P. B.; REZENDE, A. L.; JUSTO, F. B.; REZENDE, S. R.; CESAR, J. C. G.; SANTOS, M. R.; MUNDIM, A. V.; SAUT, J. P. E. Perfil metabólico de vacas Jersey clinicamente saudáveis. Pesquisa Veterinária Brasileira, Rio de Janeiro, v. 37, n. 2, p. 195203, 2017. DOI: 10.1590/s0100-736x2017000200015

Álvarez, J. A. C.; VERGARA, J. C. M.; VILLADIEGO, F. A. C.; MARTÍNEZ, R. D. B.; LEÓN, V. E. G. Frecuencia de dermatobiosis cutánea bovina en vacas Holstein de un hato lechero en Viçosa (MG, Brasil). Revista CES Medicina Veterinária e Zootecnia, 
Medelin, v. 8, n. 1, p. 82-94, 2013.

BAGGA, A.; RANDHAWA, S. S.; SHARMA, S.; BANSAL, B. K. Acute phase response in lame crossbred dairy cattle. Veterinary World, Gujarat, v. 9, n. 11, p. 12041208, 2016. DOI:10.14202/vetworld.2016.1204-1208

BERNARDO, F. D.; CONHIZAK, C.; AMBROSINI, F.; NETO SILVA, A. F.; FREITAS, F. L. C.; FRANCISCATO, C. Alterações hematológicas e bioquímicas causadas por Anaplasma marginale em bovinos com aptidão leiteira da região Sudoeste do Paraná. Revista Brasileira de Ciência Veterinária, Rio de Janeiro, v. 23, n. 3-4, p. 152156, 2016. DOI: 10.4322/rbcv.2016.048

BIRGEL JUNIOR, E. B.; NEVES, F. S.; SALVATORE, L. C. A.; MIRANDOLA, R. M. S.; TÁVORA, J. P. F.; BIRGEL, E. H. Gestation and puerperium influence over the hepatic function of Holstein cows. Ars Veterinária, Jaboticabal, v. 19, n. 2, p. 172-178, 2003.

BRINK, P.; WRIGHT, J. C.; SCHUMACHER, J. An investigation of the ability of the glutaraldehyde test to distinguish between acute and chronic inflammatory diseases in horses. Acta Veterinaria Scandinavica, Copenhagen, v. 46, n. 1-21, p. 69-78, 2005. DOI: 10.1186/1751-0147-46-69

CANAVESSI, A. M. O.; CHIACCHIO, S. B.; SARTORI, R.; CURY, P. R. Valores do perfil eletroforético das proteínas séricas de bovinos da raça Nelore (Bos indicus) criados na região de Botucatu, São Paulo: influência dos fatores etários e sexuais. Arquivos do Instituto Biológico, São Paulo, v. 67, n. 1, p. 9-17, 2000.

CHARLES, T. P.; CAMPOS, O. F.; LIZIEIRE, R. S. Uso do teste de coagulação pelo glutaraldeído como indicador do nível de imunoglobulinas no soro e sangue de bezerros recém-nascidos. Revista da Sociedade Brasileira de Zootecnia, Viçosa, MG, v. 23, n. 1, p. 65-72 1994.

DE VRIES, M.; BOKKERS, E. A. M.; DIJKSTRA, T.; VAN SCHAIK, G.; DE BOER, I. J. M. Invited review: associations between variables of routine herd data and dairy cattle welfare indicators. Journal of Dairy Science, Champaign, v. 94, n. 7, p. 3213-3228, 2011. DOI: 10.3168/jds.2011-4169

DEVERY-POCIUS, J. E.; LARSON, B. L. Age and previous lactations as factors in the amount of bovine colostral immunoglobulins. Journal of Dairy Science, Champaign, v. 66, n. 2, p. 221-226, 1983. DOI: 10.3168/ jds.S0022-0302(83)81780-9

DIRKSEN, G.; GRÜNDER, H. D.; STÖBER, M.; ROSENBERGER, G. Exame clínico dos bovinos. 3. ed. Rio de Janeiro: Guanabara Koogan, 1993. 413 p.

DOLL, K.; SCHILlingER, D.; KLEE, W. Der Glutaraldehyd-test beim Rind - seine Brauchbarkeit für Diagnose und Prognose innerer Entzündungen. Zentralblatt für Veterinärmedizin Reihe A, Berlin, Hamburg, v. 32, n. 1, p. 581-593, 1985. DOI: 10.1111/ j.1439-0442.1985.tb01978.x

FAGLIARI, J. J.; SANTANA, A. E.; LUCAS, F. A.; CAMPOS FILHO, E.; CURI, P. R. Constituintes sanguíneos de bovinos lactantes, desmamados e adultos das raças Nelore (Bos indicus) e Holandesa (Bos taurus) e de bubalinos (Bubalus bubalis) da raça Murrah. Arquivo Brasileiro de Medicina Veterinária e Zootecnia, v. 50, n. 3, p. 263-271, 1998.

FERREIRA, M. M.; MELLO, M. M.; MARQUES JUNIOR, A. P. Concentração de proteína sérica total, albumina e globulinas em novilhas Holandesas soro reagentes para leucose bovina a vírus durante a gestação e pós-parto. Revista Brasileira de Saúde e Produção Animal, Salvador, v. 1, n. 3, p. 68-73, 2001.

FÜRLL, M. Stoffwechsel- und Mangelkrankheiten. In: HOFMANN, W. Rinderkrankheiten: innere und chirurgische Erkrankungen. $2^{\text {th }}$ ed. Stuttgart: Eugen Ulmer Verlag, 2005. p. 363-463.

GONZÁLEZ, F. H. D.; SILVA, S. C. Introdução a bioquímica clínica veterinária. 3. ed. Porto Alegre: UFRGS, 2017. 519 p.

GREENOUGH, P. R. Lameness in cattle. $3^{\text {th }}$ ed. Philadelphia: Saunders, 1997. 277 p.

KANEKO, J. J.; HARVEY, J. W.; BRUSS, M. Clinical biochemistry of domestic animals. $6^{\text {th }}$ ed. Burlington: Elsevier Academic Press, 2008. 916 p.

KAWAMURA, T. Interpretação de um teste sob a visão epidemiológica. Eficiência de um teste. Arquivo Brasileiro de Cardiologia, São Paulo, v. 79, n. 4, p. 437441, 2002. DOI: 10.1590/S0066-782X2002001300015

KOVÁČ, G.; MUDRON, P.; MARTINCEK, M. Utilization of the glutaraldehyde coagulation test in cattle. Acta Veterinary Brno, Brno, v. 56, n. 3, p. $275-$ 280, 1987. DOI: $10.2754 /$ avb198756030275

LIBERG, P. The fibrinogen concentration in blood of dairy cows and its influence on the interpretation of the glutaraldeyde and formol-gel test reactions. Acta Veterinaria Scandinavica, Copenhagen, v. 19, n. 3, p. 413-421, 1978.

MCSHERRY, B. J.; HORNEY, F. D.; DEGROOT, J. J. Plasma fibrinogen levels in normal and sick cows. Canadian Journal of Comparative Medicine, Ottawa, v. 34, n. 3, p. 191-197, 1970.

MEDZHITOV, R. Origin and physiological roles of inflammation. Nature, London, v. 454, n. 7203, p. 428435, 2008. DOI: 10.1038/nature07201 
MEIRELLES, C.; DITTRICH, T.; CIPRIANO, F.; OLLHOFF, R. D. Evolução da soroprevalência da Leucose Enzoótica Bovina em um rebanho bovino leiteiro universitário. Semina: Ciências Agrárias, Londrina, v. 30, n. 3, p. 671-678, 2009. DOI: 10.5433/1679-0359.2009v30n3p671

METZNER, M.; HORBER, J.; RADEMACHER, G.; KLEE, W. Application of the glutaraldehyde test in cattle. Journal of Veterinary Medicine Series A, Berlin, Hamburg, v. 54, n. 9, p. 449-454, 2007. DOI: 10.1111/j.1439-0442.2007.00939.x

NECHANITZKY, K.; STARKE, A.; VIDONDO, B.; MÜLLER, H.; RECKARDT, M.; FRIEDLI, K.; STEINER, A. Analysis of behavioral changes in dairy cows associated with claw horn lesions. Journal of Dairy Science, Champaign, v. 99, n. 4, p. 2904-2914, 2016. DOI: $10.3168 /$ jds.2015-10109

PAULA, M. C.; MARTINS, E. N.; SILVA, L. O. C.; OLIVEIRA, C. A. L.; VALOTTO, A. A.; RIBAS, N. P. Interação genótipo $\mathrm{x}$ ambiente para produção de leite de bovinos da raça Holandesa entre bacias leiteiras no estado do Paraná. Revista Brasileira de Zootecnia, Piracicaba, v. 38, n. 3, p. 467-473, 2009. DOI: 10.1590/ S1516-35982009000300010

PERISSINOTTO, M.; MOURALL, D. J.; CRUZ, V. F.; SOUZA, S. R. L.; LIMA, K. A. O.; MENDES, A. $\mathrm{S}$. Conforto térmico de bovinos leiteiros confinados em clima subtropical e mediterrâneo pela análise de parâmetros fisiológicos utilizando a teoria dos conjuntos fuzzy. Ciência Rural, Santa Maria, v. 39, n. 5, p. 14921498, 2009. DOI: 10.1590/S0103-84782009005000094

SANDHOLM, M. Die Feststellung der Hyper-yGlobulinämie unter Praxisbedingungen. Tierärztliche Praxis, Stuttgart, v. 2, n. 2, p. 237-240, 1974.
SMITH, B. P. Large animal internal medicine. $4^{\text {th }}$ ed. Louis Missouri: Mosby Elsevier, 2009. 1825 p.

SPRECHER, D. J.; HOSTETLER, D. E.; KANEENE, J. B. A lameness scoring system that uses posture and gait to predict dairy cattle reproductive performance. Theriogenology, Los Altos, v. 47, n. 6, p. 1179-1187, 1997. DOI: 10.1016/S0093-691X(97)00098-8

STARKE, A. Personal communication during. In: CONGRESSO BRASILEIRO DE BUIATRIA, 12. 2017, Foz do Iguaçu. Veterinarian, Professor, Head of the cattle clinic of the University of Leipzig, Germany. 2017.

THRALL, M. A.; WEISER, G.; ALLISON, R.W.; CAMPBELL, T. W. Veterinary hematology and clinical chemistry. 2. ed. Danvers: Wiley-Blackwell, 2012. 762 p.

TYLER, J. W.; BESSER, T. E.; WILSON, L.; HANCOCK, D. D.; SANDERS, S.; REA D. E. Evaluation of a whole blood glutaraldehyde coagulation test for the detection of failure of passive transfer in calves. Journal of Veterinary Internal Medicine, Ohio, v. 10, n. 2, p. 82-84, 1996. DOI: 10.1111/j.1939-1676.1996.tb02032.x

VALARCHER, J. F.; HÄGGLUND, S. Viral respiratory infections in cattle. In: WORLD BUIATRICS CONGRESS, 24., 2006, Nice. Proceeding... Nice: [s.n.], 2006.

ZIMMER, C. R.; ARAÚJO, D. F.; RIBEIRO, P. B. Flutuação populacional de muscídeos (Diptera, Muscidae) simbovinos e sua distribuição sobre o corpo do gado de leite, em Capão do Leão, RS, Brasil. Ciência Rural, Santa Maria, v. 40, n. 3, p. 604-610, 2010. DOI: $10.1590 / \mathrm{S} 0103-84782010000300017$ 